\title{
De mislykkete forsøkene
}

Ved Arnhild Lauveng

Jeg har alltid vært opptatt av språk. Hvilke ord vi bruker og hvordan vi beskriver situasjoner, sier mye om hvordan vi fortolker og forstår virkeligheten. Godt språk og gode metaforer kan klargjøre vanskelige begrep og mildne krasse, men nødvendige tilbakemeldinger, på samme måte som feil ord på feil sted kan gjøre at det som i utgangspunktet er godt ment, ender opp som sårende eller bare dumt. For ordene vi bruker, er aldri bare ord. De beskriver virkeligheten slik vi oppfatter den, de avslører hva vi velger å fokusere på i en gitt situasjon, og de skaper også en virkelighet for de som hører ordene våre.

Ett av de noe pussige språkfenomenene jeg ofte reagerer på, er uttrykket mislykkete selvmordsforsøk. Jeg forstår selvsagt hva som menes; personen hadde et ønske om å ta livet av seg, men lyktes ikke i forsøket. G reit nok. Eller kanskje ikke. Det er noe med ordet mislykket som for meg blir helt feil i denne situasjonen. For jeg har vært der selv. Sittet med mitt eget liv i hendene mine, bokstavelig talt. Lett etter muligheter, kjent vekten av selvforakten presse meg nedover, vurdert alle andre alternativer uten å finne noen. Tatt et forvirret valg basert på redsel, håpløshet og fortvilelse. Våknet opp på sykehuset etter at jeg ikke beregnet å våkne opp mer. M øtt min egen sårbarhet, behandlernes travelhet og de tause eller uttalte bebreidel sene om at "dette var helt unødvendig - det er reelt syke mennesker her og så gjør du noe så dumt med vilje". Jo, jeg har vært der. $0 \mathrm{~g}$ jeg vet at det jeg trengte minst i den situasjonen, var ordet mislykket. For det var generelt sånn jeg følte meg selv. Det var slett ikke nødvendig å høre det fra andre også.

Det er nå mange år siden jeg selv var i slike situasjoner. M en etter at jeg ble frisk, tok jeg min utdannelse og arbeider i dag som psykolog. I den forbindel se har jeg hørt mange andre historier fra mennesker som heldigvis overlevde sine mest fortvilete øyeblikk - eller fra "pasienter med mislykkete suicidforsøk bak seg" for å benytte journalspråket. Det er som regel sterke historier om fortvilelse, skam, hăpløshet og desperasjon. $0 \mathrm{~g}$ flere av dem beskriver også forholdsvis mislykkete møter med hjel perne på sykehusets akuttmottak. D e forteller om stor skyldfølelse som ble forsterket av uttalelser om at "de burde tenke på de som virkelig var syke". $\mathrm{N}$ oen forteller også om direkte uetisk oppførsel, om leger og sykepleiere som ikke brukte tilstrekkelig bedøvelse, eller som beklaget at pasienten ikke var bevisst under gjenopplivning ettersom de kanskje hadde forstått hvor "dumme" de var dersom de hadde kjent smerten.

Jeg var ikke selv til stede i disse situasjonene. Jeg har ikke objektivt hørt "begge sider", jeg vet ikke hvor vanlig eller utbredt slike fenomen er. $M$ en jeg har hørt historiene fra dem som var der. Det får meg til å tro at det i alle fall forekommer av og til, og jeg reagerer umiddel bart som menneske når jeg hører det de forteller. Jeg syns det er en grusom, hard og ufølsom måte å møte sårbare personer på, og jeg syns rett og slett ikke dette er hyggelige eller høflige ting å si til folk som er fortvilte og ulykkelige. M en normal folkeskikk er bare en del av problemet, og slett ikke det viktigste. Som psykolog tenker jeg også at dette ikke er en spesielt god eller fagl ig forsvarlig måte å møte pasienter i krise på. Jeg er ikke forsker. Jeg har ikke spesialkompetanse på suicidiologi, og jeg har ikke detaljkunnskap om statistikk og mer og mindre vanlige årsaker til selvmordforsøk. M en jeg har min grunnutdanning i psykologi, og jeg har i klinisk praksis møtt en del mennesker som har overlevd sel vmordsforsøk. Disse møtene bekrefter min antagelse om at de fleste som prøver noe slikt, var dypt fortvilet da de gjorde det de gjorde.

$M$ ange sier at alt var håpløst og at de ikke så noen andre utveier. En del sier de følte seg verdiløse og tenkte at familie og venner ville hatt det bedre dersom de ikke levde lenger. $N$ oen har slitt med sykdom i lang tid og sier de ikke orker mer, at det ikke blir bedre uansett hva de prøver, og at de ikke ønsket å "være til bryderi for andre lenger". De tok et mer eller mindre overveid valg om å dø. $0 \mathrm{~g}$ så overlevde de. $0 \mathrm{~g}$ ble møtt med opplysningen om at de hadde mislyktes - igjen. A t de bare var til bry for andre - igjen. A t de egentlig ikke fortjente eller var verdige omsorgsfull og profesjonell medisinsk behandling fordi det var deres egen skyld at de var havnet i denne situasjonen. Jeg har ingen statiske an alyser av effekten av slike møter. Jeg kan ikke dokumentere hvilken innvirkning slike uttalelser har på menneskers selvfølelse, opplevelse av egenverd og føl else av å være verdifull og være verdig til å leve et godt liv. M en disse møtene har ikke hjulpet de menneskene som har fortalt meg sine historier. O g slike møter hjalp heller ikke meg da jeg var i tilsvarende situasjoner.

M en jeg har også hørt andre historier. Fra mennesker som forteller at sykehusoppholdet ble et vendepunkt i deres liv, at de for første gang møtte mennesker som hørte på dem, utforsket muligheter de selv ikke hadde tenkt over og at de opplevde å bli hørt og respektert. A t det gikk an å dele problemene med noen som var villige til å lytte, slik at de slapp å streve med dem alene. A t de fikk tilbud om videre oppfølging $i$ forhold til både følel sesmessige og praktiske vansker. A t de ble sett og at det ble formidlet håp i håpløsheten og verdighet i skammen. Enkelte har fortalt om en enorm opplevelse av selvhat, de ønsket virkelig å begå mord, å drepe seg selv. De kjente ikke lenger bare på selvforakt, men opplevde at de hatet seg selv. $0 \mathrm{~g}$ jeg har hørt fortellinger om hvordan de i dette selvhatet møtte mennesker som viste dem omsorg og vennlighet. En hånd å holde $\mathrm{i}$ under pumpingen. Tilbud om varm te eller litt mat midt på natta, et mykt teppe brettet forsiktig rundt en såret kropp. Slike møter vil neppe kunne reparere en selvfølelse og en personlighet som er skadet gjennom år, så lett er det tross alt ikke. M en jeg har hørt historiene. Det betyr at de blir husket, at de gjorde inntrykk, at de betydde noe for den som opplevde det. $0 \mathrm{~g}$ jeg husker også selv mine egne møter med de gode hjel perne. J eg syns ikke selv 
jeg fortjente noe godt, og jeg ble forundret over de som i møte med min selvdestruktivitet gjorde seg umake med å redusere smertene og være forsiktige. D e hardhendte overrasket meg ikke. Jeg var hardhendt selv, behandlet meg som om jeg var verdi løs og regnet med at jeg var det, det var ikke noe nytt $i$ at de også syntes det. M en de forsiktige, de omsorgsfulle, de som behandlet meg som om jeg skulle være noe verdt, de gjorde meg nysgjerrig på om det kanskje likevel fantes muligheter for at jeg var verdig noe godt. Jeg trodde selvfølgelig ikke på dem, sånn med en gang, men over tid gjorde møter med de forsiktige noe med både selvfølelse og selvopplevelse. For vi mennesker er flokkdyr. $H$ va vi synes om oss selv, kan aldri helt skilles fra hvordan vi blir behandlet $\mathrm{i}$ flokken vår. Blir vi behandlet som søppel, kan vi over tid komme til å tro at vi er søppel, men blir vi behandlet som verdifullt gods, kan vi kanskje - hvis ikke de opprinnelige sårene ikke er altfor dype - selv begynne å se hva vi egentlig er verdt.

Samtidig er det selvfølgelig også problemer knyttet til å gi selvskading og selvmordsforsøk for mye positiv oppmerksomhet. Dette er svært farlig atferd, og bør selvfølgelig ikke på noen måte "beIønnes" eller forherliges. Det er en reell fare for at mennesker som er sulteforet på menneskelig kontakt og omsorg og som ikke har lært seg mer hensi ktsmessige måter å formidle behov på, kan bruke selvdestruktivitet for å oppnå det de trenger. $0 \mathrm{~g}$ det er uheldig, ikke først og fremst fordi det belaster helsevesenet, men fordi det skader allerede skadede personer, påfører folk unødig smerte, forhindrer utviklingen av mer konstruktive måter å kommunisere på, og i verste fall er dødelig. Dette er virkeligheten og hverdagen innenfor helsevesenet, og det ville vært både uforsvarlig og naivt å late som problemet ikke eksisterer. Det gjør det. O g vi er nødt til å forholde oss til det. M en jeg tror likevel ikke løsningen er straff og "gjør vi det bare ubehagelig nok så lærer de sikkert til neste gang".

$M$ ye forskning, gjennom mange år, har lært oss at straff generelt er en lite hensi ktsmessig måte å fă folk til å forandre seg på. Det kan virke en liten stund, men varer sjelden og løser så godt som aldri det grunnleggende problemet. Selvfølgelig kan det av og til være gode grunner for å innføre enkelte restriksjoner i forbindel se med selvdestruktivitet, som for eksempel overføring til en annen avdeling, at andre enn primærbehandler forholder seg til personen ved selvskading eller selvmordsforsøk, eller andre tiltak som er relevante i situasjonen. Det kan selvsagt oppleves ubehagelig for den det gjelder, men er av og til, i gitte situasjoner, helt nødvendig, og det behøver heller ikke å være en måte å straffe personen på. D et er fullt mulig å formidle at handlinger har konsekvenser uten samtidig å trampe på folks selvfølelse. Innenfor det somatiske helsevesenet er det en selvfølge at man av og til må utsette mennesker for ubehagelig og iblant også smertefull behandling. Da forsøker man å minske ubehaget i størst mulig grad gjennom å gi relevant informasjon, praktisk tilrettelegging og selvføl gel ig nødvendig anestesi. Tilsvarende prosedyrer kan selvsagt også utvikles for ubehagelige situasjoner innenfor psykisk helsevern, der det er behov for å sette restriksj oner for menneskers handlinger. $0 \mathrm{~g}$ på sikt vil det som regel være mye mer fornuftig med helt andre tiltak, individuelt tilpasset den enkelte personens problemer og livssituasjon, og med utgangspunkt i hva som trengs for å bedre både liv og selvtillit.

Det er selvsagt ikke al Itid så lett. En ting er at de gode løsningene ikke alltid er tilgjengelige. Det er mangel på ressurser, det er mangel på tilbud, etter arbeidstid er legevakt og akuttmottak mange steder de eneste tilgjengelige tilbudene, og "ring og snakk med noen før det blir for ille" er ofte et meningsløst råd. For det er ingen steder å ringe.

Et annet problem er at selvmordsforsøk, selvskading og annen selvdestruktivitet gjør noe med oss som behandlere. De fleste av oss setter pris på å leve, mange frykter døden, både sin egen og å miste noen de er glad i, og opplever et ønske om død som provoserende. A nsatte på sykehus møter daglig mennesker som har alvorlige sykdommer, eller som har blitt utsatt for ulykker og som intenst ønsker å overleve. Døden er på en måte også helsearbeidernes hovedfiende. Vi skal redde liv, lindre smerte, helbrede

sykdom. M ennesker

som ønsker å dø, bryter mønsteret og forstyrrer ordenen. Det er skremmende og provoserende, det minner oss på vår egen angst og kan fremprovosere følelser av utilstrekkelighet og engstelse. $\mathrm{H}$ ar jeg eller andre sagt noe galt siden han giorde dette? Kan hun gjøre det igjen hvisjeg sier noe feil eller snakker for mye om det som hendte? Vi blir redde og usikre, og da er mi sforståelsene ofte lett tilgjengelige.

Som behandler har jeg ingen problemer med å forstå engstel sen og usikkerheten hos helsearbeidere som møter mennesker som har forsøkt å ta livet av seg, og lettelsen over at de "ikke klarte det". M en fra den tiden hvor jeg selv var pasient, husker jeg uttalelsene om at "forsøket var nå ikke så alvorlig - hadde du virkelig ment det burde du ha sikra deg enda bedre". N å forstår jeg pleiernes behov for å trøste og trygge seg selv: "D et var ikke alvorlig ment, det var aldri noen virkelig fare, hun ville bare skremme oss, det var ikke vår skyld, det er henne det er noe galt med, det er hun som er syk og vanskelig, jeg er en flink helsearbeider og jeg gjorde ikke noe galt." Forståelige, naturlige reaksjoner i en travel og ukontrollerbar hverdag. Kanskje nødvendige for å holde ut presset i situasjonen og orke å fortsette i jobben. Kanskje et resultat av for lite støtte i arbeidsmiljøet og for lite tilgang på undervisning og veiledning. M en det forstår jeg nå. Den gang hørte jeg bare en bebreidelse fordi jeg ikke hadde vært grundig nok, og en oppfordring til å være enda mer omhyggelig med planleggingen neste gang. J eg så ikke deres redsel, og de var ikke i en posisjon hvor de orket å ta inn over seg fortvilelsen som lå bak handlingene mine. Dermed misforstod vi hverandre grundig. Jeg ble såret av uttalelser som sann synligvis ikke egentlig han dlet om meg, og de oppnådde det motsatte av det de ønsket: Faren for gjentakelse $ø$ kte i stedet for å synke.

Dette handler selvfølgelig om mye mer enn ord, men det handler også om ord, fordi ord definerer virkeligheten og danner grunnlag for valgene vi tar om hva vi vil gjøre i en gitt situasjon. Et mislykket forsøk. "H an forsøkte, men ikke grundig nok." "H un fikk det ikke til, prøvde 
kanskje ikke helhjertet nok." Det gir signaler om prestasjon, vilje, viljestyrke, evner. $0 \mathrm{~g}$ det hjelper oss ikke til å løse flokene som oppstår i møtet mellom pasientens sårbarhet og personal ets hjel peløsh et. M islykket forsøk er ikke ord som hjel per oss til å se at psykisk sykdom også er sykdom, og at det er sykdommer som av og til er dødelige. På samme måte som fysisk sykdom velger ikke mennesker selv å bli syke (selv om livsstil og evne til å følge opp behandling selvsagt kan ha en innvirkning på forl øpet i enkelte tilfeller). På samme måte som ved fysisk sykdom hender det at pasienter dør, til tross for at helsearbeiderne har gitt best mulig tilgjengelig behandling. A v og til er det beste vi kan oppnå, å forlenge livet eller lindre smertene. Det er trist og brutalt, men samtidig realistisk - vi kan ikke redde alle. Denne sørgelige sannheten har samtidig en positiv side: Den sparer oss for moralisme og skyldfordeling. Selvsagt kan helsearbeidere gjøre feil og være skyldige i forsømmelser, men det er slett ikke sikkert at det er det som har skjedd dersom en pasient forsøker å ta livet av seg. Da blir det heller ikke å så avgjørende å berolige seg selv med at "forsøket ikke var seriøst nok" rett og slett fordi vurderinger av hvem som har mest skyld blir mindre aktuelt hvis vi forholder oss til en felles skjebne: en alvorlig sykdomstilstand som gjør både pasient og behandler hjelpeløse og avmektige innimellom.

Kanskje er det også derfor jeg reagerer så sterkt på uttalelser om "de mislykkete forsøkene". Jeg vet at beskrivelsen er korrekt og forsvarlig, teknisk sett. M en den fokuserer feil. Det er beskrivelser som fokuserer på mislykkethet, skam og prestasjon, som utelater mange viktige problemområder, og som ignorerer det aller viktigste: A t et menneske var dypt fortvilet og ulykkelig, men at hun eller han fortsatt lever. A t personen det gjaldt fikk ny sjanse til å leve livet sitt, uansett hvordan det ser ut, og at vi som hjelpere fikk ny sjanse til å tilby hjelp for å gjøre det livet litt mer levelig. Det er det som er det viktige. $0 \mathrm{~g}$ det er aldri mislykket å overleve.

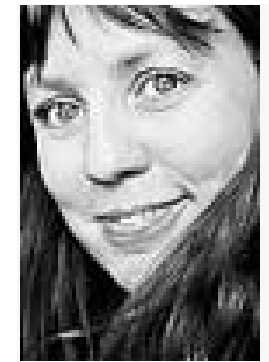

A rnhild L auveng er utdannet cand. psychol. ved $\mathrm{U}$ niversitetet i $\mathrm{O}$ slo, og arbeider i dag som psykolog ved K ongsvinger. DPS. Hun er en aktiv foredragshol der, og mottok i 2004 «Prisen til fremme av ytringsfriheten i psykisk helsevern».

FOTO: FREDRIK ARFF

A rnhild L auveng har utgitt følgende bøker:



C appelen 2005

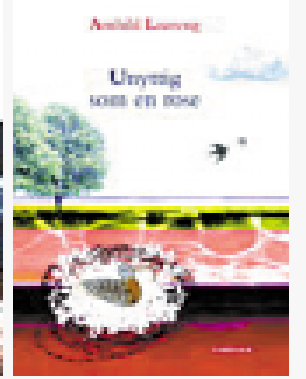

C appelen 2006 livet våkner

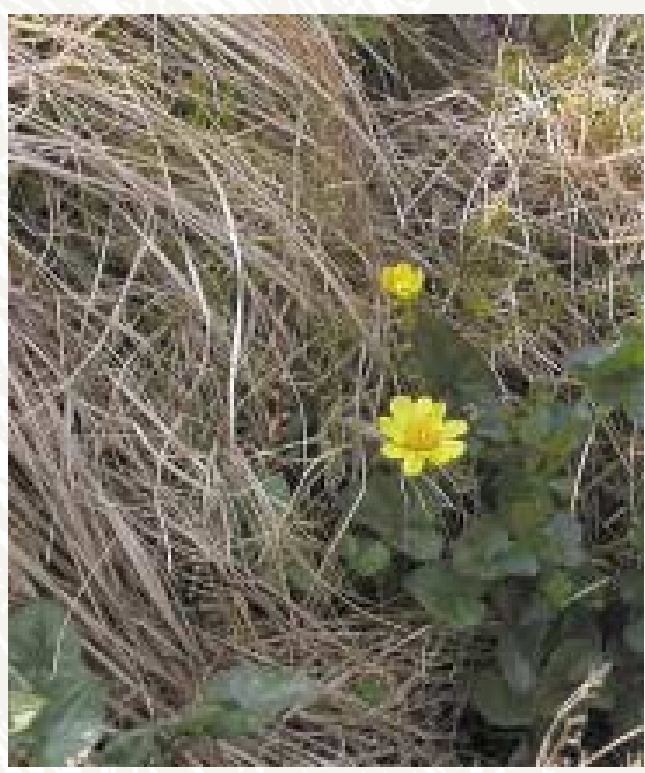

litt etter litt

vender livet tilbake

litt etter litt svinner frosten

disen letter

solen varmer

livet kjennes

det spirer

Målfrid J Frahm Jensen 